\title{
Biotechnological Alternatives for the Utilization of Dairy Industry Waste Products
}

\author{
Cortés-Sánchez Alejandro De Jesus', Valle-González Elba Ruth², \\ Salazar-Flores Rodolfo Daniel ${ }^{2}$, Ashutosh Sharma ${ }^{2 *}$ \\ ${ }^{1}$ Comisión Federal para la Protección contra Riesgos Sanitarios, Departamento de Microbiología, Tlalpan, \\ Mexico \\ ${ }^{2}$ Escuela de ingeniería en alimentos, biotecnología y agronomía, Instituto Tecnológico y de Estudios Superiores \\ de Monterrey, San Pablo, Mexico \\ Email: *asharma@itesm.mx
}

Received 12 March 2015; accepted 26 March 2015; published 30 March 2015

Copyright (C) 2015 by authors and Scientific Research Publishing Inc.

This work is licensed under the Creative Commons Attribution International License (CC BY).

http://creativecommons.org/licenses/by/4.0/

c) $\underset{\mathrm{EY}}{\mathrm{C}}$ Open Access

\begin{abstract}
The industrial obtainment and manufacturing of food cause high levels of pollution because of the generation of waste byproducts. Over the past few years, there has been a significantly increased interest in preserving, restoring and establishing an ecological balance during food production. Many investigators propose biotechnological solutions to the treatment of industrial wastes, especially waste from the dairy industry. The aim of this review is to present biotechnological approaches to the treatment and utilization of wastes from the dairy industry, specifically for milk whey and also discussed biotechnological methods to reduce environmental pollution and obtain chemical compounds with potential applications in the industry.
\end{abstract}

\section{Keywords}

Bioactive Peptides, Milk Whey, Organic Acids, Biofuel, Biosurfactants

\section{Introduction}

Traditionally, milk has been considered the most complete food provided by nature. It is an important source of essential nutrients needed for the growth and development of newborns. It is also highly recommended in the diet of adult humans due to its high nutritional value [1]. Milk is defined as a biological secretion from the mammary glands of female mammals. It is mainly composed of water, proteins, lipids, carbohydrates, vitamins and minerals (Table 1) [1] [2].

${ }^{*}$ Corresponding author.

How to cite this paper: De Jesus, C.-S.A., Ruth, V.-G.E., Daniel, S.-F.R. and Sharma, A. (2015) Biotechnological Alternatives for the Utilization of Dairy Industry Waste Products. Advances in Bioscience and Biotechnology, 6, 223-235.

http://dx.doi.org/10.4236/abb.2015.63022 
Table 1. Principal components of cow milk [1] [2].

\begin{tabular}{cc}
\hline & Principal components of cow milk \\
Water & $78.8(\mathrm{~g})$ \\
Lactose & $4.7(\mathrm{~g})$ \\
Proteins & $3.3(\mathrm{~g})$ \\
Lipids & $3.3(\mathrm{~g})$ \\
Minerals & $0.7(\mathrm{~g})$ \\
Vitamins & \\
Retinol & $35.0(\mu \mathrm{g})$ \\
Carotene & $16.0(\mu \mathrm{g})$ \\
Vitamin A & $37.0(\mu \mathrm{g} \mathrm{RE})$ \\
Vitamin E & $0.08(\mathrm{mg})$ \\
Thiamin & $0.04(\mathrm{mg})$ \\
Riboflavin & $0.20(\mathrm{mg})$ \\
Niacin & $0.13(\mathrm{mg})$ \\
Pantothenic acid & $0.43(\mathrm{mg})$ \\
Vitamin B6 & $0.04(\mathrm{mg})$ \\
Folate & $8.50(\mu \mathrm{g})$ \\
Biotin & $2.0(\mu \mathrm{g})$ \\
Vitamin B12 & $0.51(\mu \mathrm{g})$ \\
Vitamin C & $1.0(\mathrm{mg})$ \\
Vitamin D & $0.20(\mu \mathrm{g})$ \\
\hline
\end{tabular}

Lactose is the principal carbohydrate found in milk. It has been reported that lactose can stimulate the absorption of minerals including calcium and magnesium [3]. Maclura are the principal lipid constituents, representing 98\% of the total fat in milk. Diglycerides, monoglycerides, esters and cholesterol are found at low levels [4]. The function of the lipid materials in milk is to transport the fat-soluble vitamins A, D and E [4] [5]. Moreover, it has been demonstrated that milk not only contains nutritive compounds but also biologically active ones, like caseins and whey proteins. Caseins constitute $80 \%$ of the total protein present in milk; the other $20 \%$ is comprised of the whey proteins including $\alpha$-lactalbumin, $\beta$-lactoglobulin and immunoglobulins [2]. However, several aspects such as diet, breed, geographical conditions, illness and other factors can modify the proportions of the nutrients in milk. Mineral content is the component most affected by these factors [6]. Milk produced by many different mammalian species is consumed by humans, but cow's milk is the most commonly consumed. Milk from cows is produced in large quantities in countries including United States, India and China (Table 2) [7].

Because of its high nutritional content, milk can be used to produce a large variety of dairy products such as whole, skim, lactose-free and fat free milk; or even whole or skimmed milk powder. Additional products include condensed and evaporated milk, which can be pasteurized or ultra pasteurized. Milk is also used to produce the fermented dairy products cheese, yogurt, kefir and bulgaro. Butter, milk whey, sweet/sour cream, case inacid type, lacticorrenin, caseinates, lactose, enzymatically modified milk ingredients, cream, ice cream and other dairy beverages, are the main products we obtain from milk [9] [10]. The per capita ingestion of milk and its various derivatives has decreased worldwide, excepting the consumption of cheese. Currently, Ireland is the largest consumer of liquid milk, and France is the largest consumer of dairy products like butter and cheese (Table 3 and Table 4) [11].

The manufacturing of dairy products represents a great concern because of pollution and damage to the environment. This problem is due to the generation of waste from livestock producers and the by-products from 
Table 2. Milk producer countries around the world in 2011 [8].

\begin{tabular}{ccc}
\hline \multicolumn{3}{c}{ Major milk producers around the world } \\
\hline Country & Production (Tons) \\
\hline United States & $89,015,235$ \\
India & $57,400,000$ \\
China & $36,928,896$ \\
Brazil & $32,096,214$ \\
Russia & $31,385,732$ \\
Germany & $30,301,359$ \\
France & $24,361,095$ \\
New Zealand & $17,893,848$ \\
\hline
\end{tabular}

Table 3. Milk consumption in several countries around the world in 2012 [8].

\begin{tabular}{ccc}
\hline Country & Liters per capita \\
\hline Ireland & 135.6 \\
Finland & 128.3 \\
United Kingdom & 102.9 \\
Iceland & 96 \\
Canada & 77 \\
United States & 74 \\
Uruguay & 67.1 \\
Brazil & 57.2 \\
Israel & 53.7 \\
India & 40 \\
México & 34.8 \\
South Africa & 23.1 \\
\hline
\end{tabular}

Table 4. Dairy consumption in various countries around the world in 2012 [11] [12].

\begin{tabular}{cccc}
\hline & & Kg per capita & \\
Country & Cheese & Butter \\
\cline { 2 - 4 } France & 26.3 & 7.4 \\
Iceland & 25.2 & 4.9 & 4.5 \\
Finland & 23.7 & 0.9 & 2.5 \\
Israel & 17.1 & 2.8 \\
United States & 15.2 & 3.4 \\
Canada & 12.1 & 11.2 & 2.4 \\
United Kingdom & 6.7 & 1.6 \\
\hline
\end{tabular}


dairy foods [13]-[15]. This kind of pollution affects the quality of water, air and soil. It even causes climatic variations [16].

Milk whey is a liquid by-product produced during the manufacturing process of cheese. It represents $85 \%$ $90 \%$ of the original milk volume and retains $55 \%$ of the nutrients. Milk whey has proteins, lipids, soluble vitamins, minerals and carbohydrates. Of the total whey solids, $75 \%$ is lactose. Lactose is one of the most polluting by-products because of its high biochemical oxygen demand (BOD) $<35,000 \mathrm{ppm}$ and its chemical oxygen demand (COD) < 60,000 ppm [17]. If this industrial effluent is discarded in the soil without prior treatment, it can modify the soil's physical and chemical composition, reducing crop yields and the availability of oxygen in water [15] [18] [19]. It has been estimated that 40,000 liters of untreated milk whey produces contamination equivalent to that produced daily by a population of 250,000 people [20]. Another by-product from the dairy industry is clarified butter sediment waste derived from the manufacturing of clarified or ghee butter. This butter waste is mainly composed of fats in the form of fatty acids and small amount of proteins [21]. It has been found that discarding milk whey in the water of rivers and lakes causes enormous pollution problems because of the large amounts of nitrogen, and phosphorus and high BOD (40 - 48,000 mg/L) and COD (89 $95,000 \mathrm{mg} / \mathrm{L}$ ) contained in this by-product [22]. The conditions mentioned above promote the process of eutrophication, causing an excessive growth of microorganisms and aquatic plants [23] [24].

The aim of this review is to present milk as a nutritious food for human consumption and describe its use as a raw material for manufacturing a variety of dairy products. However, in this present analysis it has been emphasized that the manufacturing processes of many dairy products produce large amounts of by-products that are discarded in the ecosystem, causing considerable environmental problems. Thus, scientists around the globe are looking for new biotechnological alternatives to utilize those by-products to obtain chemical compounds with potential applications in different industrial areas and to reduce the environmental damage.

\section{Biotechnological Alternatives for the Use of By-Product Wastes from the Dairy Industry}

In the last few years a social, political, scientific and technological interest in environmental protection has emerged. An international effort is underway to discover solutions to environmental problems and to create a balance between human development and care of our ecosystem. Alternatives developed by researchers for the utilization of waste of the dairy industry are discussed in the following section.

Biomass: In the process of olive oil extraction $20 \%$ of the oil is extracted and the other $80 \%$ is a waste called oil press, where $50 \%$ of oil press is composed of water. This water contains a mixture of extracts from the plant material, soft tissue of olives and water used in any stage of the extraction process [25]. Recently it was discovered that Geotrichum candidum, a fungus that produces lignolytic enzymes, might clear this residual wastewater from the industrial processes. The idea of using a mixture of oil press water and milk whey as a substrate to produce biomass came out because of the favorable features of this fungus [26]. The experiment was run for 5 days at $30^{\circ} \mathrm{C}$ under aerobic conditions using a mixture 20:80 of oil press water and milk whey respectively. The results reported high growth of the fungus, a clearance of $54.4 \%$ of the media mixture and a $55.3 \%$ reduction in phenolization. It was concluded that oil press waste and milk whey are the cheapest and most effective substrates to obtain biomass from G. candidum. An added benefit is that the process also reduces pollution levels. Moreover, the microbial biomass contains a large amount of protein that could be a potential option for human consumption. Yeast like Kluyveromyces marxianus var. marxianus can be grown under anaerobic conditions in batch cultures with milk whey. This fermentation process is considered a good source of unicellular protein because it shows a balanced amino acid profile according to the international standards from FAO (lysine $5.5 \mathrm{~g} / 100 \mathrm{~g}$ and methionine andcysteineare $1.73 \mathrm{~g} / 100 \mathrm{~g}$ ) [27].

Bioplastics: Several studies have focused on the production of bioplastics like polyhydroxyalkanoates (PHA), which have shown to be good substitutes for plastics derived from highly polluting oil. PHAs are biodegradable polymers synthesized by bacteria in the presence of an excess of carbon. Bacillus megaterium SRKP-3 produces polyhydroxybutyrates (PHB), the most common type of PHA. To produce PHB, industrial dairy waste can be used as substrate. An optimal production yield of PHB $(6.37 \mathrm{~g} / \mathrm{L})$ is achieved in $30 \mathrm{~h}$ at $30^{\circ} \mathrm{C}$. The maximum production yield (11.32 g/L) was obtained in $36 \mathrm{~h}$ in an optimized medium [28]. Furthermore, the use of PHAs is not only helpful for the environment, but has also come to have great impact in the medical field. Brevibacterium casei SRKP2, which can utilize industrial waste milk as a carbon source, also produce PHB [29]. This 
bacterium was shown to produce $2.940 \mathrm{~g} / \mathrm{L}$ of PHB in $48 \mathrm{~h}$ at $37^{\circ} \mathrm{C}$ in a submerged culture. The products were used to produce nanoparticles of PHB to facilitate the delivery of drugs to any part of the body.

Biofuels and bioenergy: Another important contributing factor to environmental pollution is the burning of fossil fuels, which causes substantial harm to the atmosphere and contributes to climate change. A viable solution to this problem is the production of biofuels. The combustion of biofuels releases less polluting agents into the environment than burning fossil fuels [30]. Unfortunately, the production of biofuels has been more expensive than the production of conventional fuels due to the high cost of the raw materials [31]. Dairy wastes have been proposed as a solution because they can be used as substrate for fermentation by yeast like Kluyveromyces fragilis. These types of yeast are commonly used to hydrolyze lactose present in milk whey. The acquired ethanol from the hydrolyzation could be used to produce alcoholic beverages or for other industrial applications [32]. A study has also been conducted to examine how the concentration of milk whey affects the production of ethyl alcohol by Kluyveromyces fragilis. A maximum yield of $35.2 \mathrm{~g} / \mathrm{L}$ of ethanol was achieved using an inoculum of $10 \%$ in a batch culture ( $200 \mathrm{rpm} / 30^{\circ} \mathrm{C} / 24$ hours) and subsequently subjected to a process of anaerobic fermentation for $34 \mathrm{~h}$, utilizing $20 \%$ whey milk. However, this study also recommended the whey concentrations less than 15\% (96 g/L lactose) for an efficient alcoholic fermentation with Kluyveromyces fragilis because higher concentrations cause inhibition of the process [33]. Furthermore, whey powder has also been considered as a substrate to produce ethanol using yeast species Kluyveromyces marxianus DSMZ-7239 [34]. This yeast metabolize lactose with a yield of $0.54 \mathrm{~g}$ ethanol/g lactose. On the other hand, thermotolerant yeasts like Candida inconspicua W16 are also able to produce ethanol from whey with higher yields. The yeast was immobilized in alginate calcium gel $(3.03 \pm 0.02 \mathrm{v} / \mathrm{v})$ for $72 \mathrm{~h}$. This technique eliminates the problems of cost associated with the production of ethanol from whey [35]. In the case of the production of other biofuels such as butanol, it has been shown that the bacterium Clostridium acetobutylicum DSM 792 is capable of producing 1.5 $\mathrm{g} / \mathrm{L}$ of biobutanol through the fermentation of milk whey with a lactose concentration of $4.5 \%$ to $5 \%$; in a period of 5 days at $37^{\circ} \mathrm{C}$ and $150 \mathrm{rpm}$ in a batch culture. The fermentation process also yields minor amounts of other biofuels such as butyric acid and ethanol (less than $10 \mathrm{~g} / \mathrm{L}$ ), and produces $40 \mathrm{~g} / \mathrm{L}$ acetic acid [36]. The development of new alternative and renewable sources as substitutes for the use of electric energy has also been considered. For example, microbial fuel cell technology has been developed to obtain bioelectricity from milk wastes [37]. Many microorganisms that can be used as electron donors for biofuel batteries have been identified. The microorganisms are able to convert organic material into energy via redox reactions. The operation of a biofuel cell is similar to that of a conventional fuel cell with the major difference that the first one uses enzymes, bacteria and other microorganisms as catalysts under mild conditions of temperature and pressure. According to another study, bioelectricity can be obtained using milk whey and Saccharomyces cerevisiae PTCC 5269 cells. This yeast is able to use existing sugars in the substrate, generating a stable voltage for two days and an energy and a maximum current of $470 \mu \mathrm{A}$ and $50 \mu \mathrm{W}$ [38]. Prokaryotic organisms like E. coli are also able to use milk whey as substrate. The milk whey must first be acidified to remove excess proteins; this has to be done to facilitate the assimilation of carbohydrates. Then, bioelectricity can be generated at room temperature with a voltage of the open circuit in the absence of the mediator of $751.5 \mathrm{mV}$ at stable conditions for more than $24 \mathrm{~h}$. The maximum power of energy and current is $324.8 \mathrm{iW}$ for riboflavin and 1194.6 iA for humic acid [39].

A promising option to reduce greenhouse gas emissions, reduce the contamination of soil and aquatic ecosystems by fossils fuels, and facilitate the disposal of dairy waste is to use the wastes to produce hydrogen as a biofuel. Hydrolysis of the substrates that are used to generate $\mathrm{H}_{2}$ is a limiting step in the anaerobic production of $\mathrm{H}_{2}$. However, it has been reported that waste water from the dairy industry can be used to overcome this problem. This water must be pretreated with a sodium salt of sulfonic acid and 2-bromoethane at a concentration of 0.2 $\mathrm{g} / \mathrm{L}$ for $24 \mathrm{~h}$. Once the waste water is pretreated, the metabolic participation of an anaerobic microbial mixture is needed to allow the water to be used as a source of carbon to generate biohydrogen $\left(\mathrm{H}_{2}\right)$. The anaerobic microbial mixture must be cultivated for $18 \mathrm{~h}$ for a production of $0.025 \mathrm{mmol}$ and a substrate removal efficiency (chemical oxygen demand) up to $70 \%$ [40]. Photoproduction is another way to generate $\mathrm{H}_{2}$ using bacteria like Rhodopseudomonas Cyanobacterium Anacystis which presented a growth of 50\% - 60\% and produce approximately $70 \%-90 \%$ of $\mathrm{H}_{2}$. This kind of production is better than that seen with the growth of the microorganisms under typical laboratory conditions and culture media [41]. Another viable solution to produce biofuel and treat wastewater from the dairy industry is the use of Chlorella pyrenoidosa, a seaweed that is able to utilize the nutrients from residual water as a culture medium. The seaweed removes between $80 \%-85 \%$ of the phosphorus content, and $60 \%-80 \%$ of the nitrogen in the wastewater; generating a biomass of $18.8 \mathrm{~g} / \mathrm{L}$ and a biofuel 
production of $6.7 \mathrm{~mL}$ after 15 days of culture [42].

Organic acids: The manufacturing industries of food, beverages and pharmaceuticals demand a variety of chemical compounds, which are used as additives for the production of many products. These additives can act as acidifying agents, stabilizers, flavor enhancers or preservatives. Some examples of additives are the organic acids (citric, lactic, succinic and propionic acid) [43]-[47]. Numerous investigations have focused on finding new additives that satisfy consumer demand and are simultaneously compatible with care for the environment [47]. An efficient way to produce citric acid with Aspergillus niger ATCC9642 from milk whey was reported [48] The milk whey was supplemented with different types and concentrations of sugars, vitamins and minerals. The quantity of citric acid obtained from the culture media was $106.5 \mathrm{~g} / \mathrm{L}$ after 16 days of culture. Other fungi, including Aspergillus carbonarius NRRL 368, Aspergillus niger NRRL 3, and Aspergillus carbonarius NRRL 67 are capable of producing citric acid from whole sweet milk serum in a culture medium under optimal conditions ( $30^{\circ} \mathrm{C} / 180 \mathrm{rpm} / 8$ days). The last strain, Aspergillus carbonarius NRRL 67, showed the highest production of $6.72 \mathrm{~g} / \mathrm{L}$ [47]. The production of lactic acid has been accomplishedin mixed and individual cultures of yeast (Kluyveromyces marxianus IFO 288), and two lactic acid homofermentative bacteria (Lactobacillus delbrueckii ssp. Bulgaricus and Lactobacillus helveticus ATCC-11842, ATCC-15009) using milk whey as a unique source of substrate. It was reported that the maximum production of lactic acid was $19.8 \mathrm{~g} / \mathrm{L}$ with a yield of $0.47 \mathrm{~g}$ of lactic acid per gram lactose [49]. The use of industrial waste from yogurt production as a substrate was also reported [47]. The yogurt waste was fermented to obtain lactic acid from Lactobacillus casei ATCC393 under controlled $\mathrm{pH}$ conditions and yeast extract of preculture stage. The maximum production was obtained 36 $\mathrm{h}$ later and it was of $25.9 \mathrm{~g} / \mathrm{L}$; this demonstrates the viability and environmental friendliness of this alternative method. Another important product is succinic acid. It is mainly produced by the petrochemical industry and its production causes large amounts of pollution. An alternative approach for the reduction of environmental pollution is a biotechnological method that uses milk whey and the microorganism Actinobacillus succinogenes $130 \mathrm{Z}$, to produce succinic acid. A maximum production of $27.9 \mathrm{~g} / \mathrm{L}$ of succinic acid was achieved within 48 hours of fermentation using an initial whey concentration of $100 \mathrm{~g} / \mathrm{L}$ with an inoculum size of 5.0\% [46].

The propinobacterias have been used either as silage inoculants or to synthesize multiple functional compounds, including propionic acid. The propionic acid is primarily used as a preservative, to produce vitamin B12 or to generate biomass, as it is considered a probiotic agent [43] [44]. In a culture media enriched with pasteurized sweet milk whey at a concentration of $70 \mathrm{~g} / \mathrm{L}$ for $72 \mathrm{~h}$ in a mesophilic temperature condition, Propionibacterium shermanii is able to grow and produce up to $10 \mathrm{~g} / \mathrm{L}$ of propionic acid [43]. Propionibacterium acidipropionici can produce $32 \mathrm{~g} / \mathrm{L}$ of organic solvent and $78 \mathrm{~g} / \mathrm{L}$ of biomass if it is grown in filtrated sweet milk whey from swiss cheese production process. The whey can be fermented in a semi-continuous culture at a temperature of $32^{\circ} \mathrm{C}$, at a neutral $\mathrm{pH}$ and at $200 \mathrm{rpm}$ for 8 days [44]. Moreover, lactose can be chemically transformed through enzymatic and microbial processes to obtain lactobionic acid. Lactobionic acid is a high value product with potential applications as a bioactive molecule in the food and pharmaceutical industries [50]. It is also considered a functional ingredient because of its applications as a prebiotic, acidulant, antioxidant, firming agent and as a chelating agent of metal ions such as Fe [51]. The bacteria Pseudomonas sp. LS13-1 is capable to produce $175 \mathrm{~g} / \mathrm{L}$ of lactobionic acid using milk whey as a substrate in a fed-batch fermentation process of $180 \mathrm{~h}$. Meanwhile [52]. On the other hand, Pseudomonas taetrolens produces $1.12 \mathrm{~g} / \mathrm{L}$ of lactobionic acid, using milk whey from cheese production as substrate under batch culture conditions with $30 \%$ of inoculum [53]. Moreover, the milk whey had a $\mathrm{pH}$ of 6.4 during the growth phase and, later the $\mathrm{pH}$ was maintained at 6.5. It could be concluded that production of lactobionic acid by Pseudomonas taetrolens is economically a good option. Other important organic acids are the ones used in agriculture industry, like gibberellic acid. Gibberellic acid is a phytohormone involved in the plant growth and development. Recently it has been reported that the fungus Fusarium moniliforme produces secondary metabolites, including gibberellic acid. The production of the organic acid was achieved using waste from the dairy industry, specifically milk whey supplemented with $\mathrm{Mg}^{+2}$ ions. The maximal growth of biomass was obtained in 6 days of culture $(6 \mathrm{~g} / \mathrm{L})$ and the maximum production of gibberellic acid was with $750 \mathrm{mg} / \mathrm{L}$ after 12 days of culture [54].

Biosurfactants: Biosurfactants (BS) are amphipathic molecules due to their possession of both hydrophilic and hydrophobic chemical groups. They possess surface activity; this means that they reduce the surface tension of liquids. They are also extracellular compounds synthesized by yeasts, fungus and bacteria. The most significant characteristics displayed by them are surface activity, biodegradability, antimicrobial effects, antitumor activity, anti-adhesive, low toxicity and effectiveness at extremes of temperature, $\mathrm{pH}$ and salinity [55]-[58]. Due to these 
features, biosurfactants have great importance in bioremediation and oil recovery processes. They are important in the pharmaceutical, agriculture, cosmetics and food industries. Yeast, including Candida bombicola ATCC 22,214 , is able to synthesize BS as sophorolipids at concentrations of up to of $5 \mathrm{~g} / \mathrm{L}$ in a synthetic medium that emulates wastewater form the dairy industry [58]. Similarly, Bacillus licheniformis M104 is able to grow in milk whey and produce a BS lipopeptide with antimicrobial activity against some gram-positive strains and pathogenic enterobacteria [59]. It was concluded that milk whey maybe a comparatively better medium to produce BS without the addition of specific nutrients to the culture. On the other hand, the bacteria Pseudomonas aeruginosa ATCC 10,145 and its recombinant strain can synthetize BS with milk whey waste from the cheese industry. The process takes $96 \mathrm{~h}$ at $100 \mathrm{rpm}$. The wildtype strain achieves a production of $4000 \mathrm{mg} / \mathrm{L}$ at $30^{\circ} \mathrm{C}$ and $7500 \mathrm{mg} / \mathrm{L}$ at $37^{\circ} \mathrm{C}$. The recombinant strain generates $7000 \mathrm{mg} / \mathrm{L}$ at $30^{\circ} \mathrm{C}$ and $10,500 \mathrm{mg} / \mathrm{L}$ at $37^{\circ} \mathrm{C}$. Finally, it can be inferred that genetic engineering could improve the yields of functional compounds from industrial waste [60].

Exopolysaccharides: Exopolysaccharides (EPS) are biopolymers composed of repeated carbohydrate units. They are commonly divided in two groups: the homopolymers, composed of a single type of sugar, and heteropolymers, made up of different types of sugars. Both types of polymers may contain organic and inorganic substituents, and the lactic and halophilic bacteria produce them extracellularly [61] [62]. These compounds allow the microorganisms to adhere to the surfaces, facilitate the formation of biofilms and protect the organisms against environmental agents. EPS show functional properties that can be applied in the food and pharmaceutical industries. These include acting as emulsifiers, viscosifiers, stabilizers, texturizers, detoxifiers, and antineoplastic agents [63] [64]. The production of EPS by a Bulgaricus strain using partially hydrolyzed proteins of Cheddar cheese whey were in a range from 95 to $110 \mathrm{mg}$ EPS/L. The used whey was hydrolyzed with flavourzyme and then fermented at $38^{\circ} \mathrm{C}$, with a $\mathrm{pH}$ of 5.0, using Lactobacillus delbrueckii ssp. [65]. In contrast, the maximum output from Streptococcus thermophilus SY was $152 \mathrm{mg} / \mathrm{L}$ using a culture medium containing deproteinized whey and yeast extract. The fermentation conditions for the deproteinized whey were $12 \mathrm{~h}$, a pH of 6.4 , and a temperature of $36^{\circ} \mathrm{C}$. The obtained EPS were composed of glucose, rhamnose and galactose; their respective dispersions in water demonstrated a pseudoplastic behavior and comparable viscosity level with commercial solution sofxanthangums [66].

Bioactive peptides. In the last couple of years, compounds of protean nature with biological activity have been found in milk and in its derivatives. These compounds have been called bioactive peptides because they have a nutritional function and can exert different biological properties such as: antihypertensive activity, antimicrobial activity, vessel regulation, hormonal induction, generation of neurotransmitters, antioxidant activity, immune system regulation, antithrombotic, anti-cancer (or neoplastic), prevention of chronic diseases and facilitation of nutrient absorption. Typically, milk, colostrum and whey are the main sources of these compounds [67]-[72]. Bioactive peptides have been defined as inactive amino acid sequences found in the core of a precursor protein, which have biological activities after being released by a chemical or enzymatic hydrolysis. Depending on the nature of the precursor protein source, the types of enzymes involved and the conditions under which the active peptides are released varies [72]. The release of the bioactive peptides can occur during digestion in the stomach or during commercial fermentation processes by the metabolic activity of multiple microorganisms. During the manufacturing of yogurt or cheese, lactic acid bacteria are important for the production of bioactive peptides. The metabolic activities involve proteolytic systems that include proteinases, intracellular peptidases, endopeptidase, aminopeptidase, dipeptidase and tripeptidase. Biomolecules can also be added to regular dairy products, meat products, bakery products, confectionery, beverages and special foods specifically designed for people with high blood pressure, diabetes, high cholesterol or obesity. The bioactive peptides produced can be used as dietary supplements for human consumption because of their structure, rapid absorption, and timely elimination [73] [74].

There are several studies which showed different ways to obtain bioactive compounds using biotechnological tools. One example is a proteolytic vegetal enzyme from Maclura pomifera. The isolation of bioactive peptides depends on the cogulation of the milk via the addition of latex from Maclura pomifera. Once the milk is coagulated, peptides may be obtained from the sera. The peptide produced by this way has antioxidant properties and inhibits the angiotensin-converting enzyme [75]. The angiotensin converting enzyme is known to play a role hypertension and is a target of several anti-hypertension drugs. Furthermore, milk whey fermented by Lactobacillus helveticus increases bone density and osteoblast formation in comparison with normal whey. This study was based on in-vitro and in-vivo models. These properties were attributed to the peptides formed by the proteolytic activity of the bacteria or to increased bioavailability of proteins [76]. Such studies suggest the need forclinical 
studies to provide a better understanding of the biological effects of the fermention products and their effects against osteoporosis. The anionic and cationic peptidic fractions obtained from hydrolyzed whey proteins showed emulsifying properties at alkaline $\mathrm{pH}$. The anionic fractions demonstrated a better antioxidant activity. During this process whey hydrolyzation was achieved by incubation with vegetal cysteine proteinases such as papain and hemisphericine for a period of 360 minutes [77]. It is noteworthy that the proportion of peptides obtained either from anionic and cationic character as well as their functional properties, exhibit differences depending on the type of protease used in the hydrolysis.On the other hand, adding proteases and peptidases of Aspergillus oryzae to a concentrate of whey protein from goat cheese, and the subsequent incorporation of lactic acid bacteria like Lactobacillus helveticus and St. Salivarius var. thermophilus produce a hydrolyzed mixture that contains bioactive peptides [78]. Moreover, the bioactive peptides obtained had higher inhibitory activity against the angiotensin-converting enzyme (ACE). It could be inferred that this process could allow the use of goat whey to help prevent hypertension.

Hydrolysates. Recently enzymatic hydrolysates of proteins have been introduced into the human diet. These hydrolysates are rich in oligopeptides that improve the utilization of proteins. They have been employed in several countries as dietary supplements for middle-aged people, premature babies, athletes that control their weight, and children with diarrhea. These hydrolyzed proteins allow higher absorption of amino acids from the

Table 5. Microorganisms used in the bioremediation of the dairy industry wastes.

\begin{tabular}{|c|c|c|c|}
\hline $\begin{array}{l}\text { Microorganisms or biological } \\
\text { component used }\end{array}$ & Products & $\begin{array}{l}\text { Potential industrial } \\
\text { uses or applications }\end{array}$ & Ref. \\
\hline Geotrichum candidum & $\begin{array}{c}\text { Biomassdegradation of } \\
\text { phenol-derived compounds }\end{array}$ & Bioremediation & {$[26]$} \\
\hline Kluyveromyces marxianus var. marxianus & Unicelular protein & Food & [27] \\
\hline $\begin{array}{l}\text { Bacillus megaterium SRKP-3, } \\
\text { Brevibacterium casei SRKP2 }\end{array}$ & Polyhydroxyalkanoates (PHA) & Plastics & $\begin{array}{l}{[28]} \\
{[29]}\end{array}$ \\
\hline $\begin{array}{l}\text { Kluyveromyces fragilis, } \\
\text { Kluyveromyces marxianus DSMZ-7239, } \\
\text { Clostridium acetobutylicum DSM 792, } \\
\text { E. coli, } \\
\text { Rhodopseudomonas cyanobacterium, } \\
\text { anacystis }\end{array}$ & Etanol, butanol, electricity, $\mathrm{H}_{2}$ & Bioenergy or biofuels & $\begin{array}{l}{[32]} \\
{[33]} \\
{[34]} \\
{[36]} \\
{[39]} \\
{[41]}\end{array}$ \\
\hline $\begin{array}{l}\text { Propionibacterium shermanii, } \\
\text { Propionibacterium acidipropionici, } \\
\text { Actinobacillus succinogenes } 130 Z \text {, } \\
\text { Aspergillus carbonarius NRRL 67, } \\
\text { Aspergillus niger ATCC } 9642, \\
\text { Kluyveromyces marxianus IFO 288, } \\
\text { Lactobacillus delbrueckii ssp. Bulgaricus, } \\
\text { Lactobacillus helveticus ATCC-11,842, } \\
\text { Fusarium moniliforme }\end{array}$ & $\begin{array}{l}\text { Citric acid, lactic acid, succinic } \\
\text { acid, propionic acid, gibberellic } \\
\text { acid }\end{array}$ & $\begin{array}{l}\text { Pharmaceuticals, } \\
\text { food industry, } \\
\text { agriculture }\end{array}$ & $\begin{array}{l}{[43]} \\
{[44]} \\
{[46]} \\
{[47]} \\
{[48]} \\
{[49]} \\
{[49]} \\
{[49]} \\
{[54]}\end{array}$ \\
\hline $\begin{array}{l}\text { Candida bombicola ATCC 22,214, } \\
\text { Bacillus licheniformis M104, } \\
\text { Pseudomonas aeruginosa ATCC 10,145 }\end{array}$ & Biosurfactants & $\begin{array}{l}\text { Food industry, } \\
\text { medicine, } \\
\text { pharmaceutics }\end{array}$ & $\begin{array}{l}{[58]} \\
{[59]} \\
{[60]}\end{array}$ \\
\hline $\begin{array}{l}\text { Lactobacillus delbrueckii ssp., } \\
\text { Streptococcus thermophilus SY }\end{array}$ & Exo polysaccharides & $\begin{array}{l}\text { Pharmaceutics, food industry, } \\
\text { stabilizers, texturing and gelling } \\
\text { agents. }\end{array}$ & $\begin{array}{l}{[65]} \\
{[66]}\end{array}$ \\
\hline $\begin{array}{l}\text { Proteolytic enzymes of Maclura } \\
\text { pomifera-papain and hemisphericine }\end{array}$ & Bioactive peptides & $\begin{array}{l}\text { Pharmaceutics, food industry, } \\
\text { health }\end{array}$ & {$[75][77]$} \\
\hline Lactobacillus helveticus & Bioactive peptides & & {$[76]$} \\
\hline $\begin{array}{l}\text { Proteases and peptidases of Aspergillus oryzae, } \\
\text { Lactobacillus helveticus, } \\
\text { St. Salivarius var. thermophilus }\end{array}$ & Bioactive peptides & & {$[78]$} \\
\hline $\begin{array}{l}\text { Bacillus subtilis and proteases of Bacillus } \\
\text { licheniformis }\end{array}$ & Hydrolyzed protein & Food and nutrition & $\begin{array}{l}{[79]} \\
{[80]}\end{array}$ \\
\hline
\end{tabular}


stomach in comparison with unhydrolyzed proteins [78]. For this reason a process to obtain high yield enzymatic hydrolysates from milk whey has been designed in which milk whey was incubated for 5 hours with subtilis in enzymes of Bacillus subtilis and pancreatin from pork; and the obtained yields were $41.4 \%$ and $37.1 \%$ respectively [79]. A different process has been shown to generate hydrolyzed protein from milk whey in a manner that reduces the allergenic properties of the product by up to $99.97 \%$. Proteases from Bacillus licheniformis were used $\left(16 \mathrm{~h} / 50^{\circ} \mathrm{C} / \mathrm{pH}\right.$ 8.5) to obtain the sehydrolysates. Moreover, the product may be suitable for the incorporation into infant food and nutritional products [78] [80]. All bioremediation processes used to treat dairy waste products have been summarized in the Table 5 .

\section{Conclusion}

The byproducts of the dairy industry, like whey or sewage, are highly polluting wastes if they are deposited directly into the rivers, lakes, seas or soil. Nowdays, there are many biotechnological alternatives available that allow the use of organic wastes as substrates for useful processes. Dairy by-products can be used to obtain valuable chemical compounds that are useful in the fields of health, pharmaceuticals, food, plastics and fuels. The described strategies contribute to decreased environmental pollution and reduce the damage caused by man. In short, multiple proposals exist and others are being developed. However more studies are required to optimize the culture conditions and to develop microbial strains to obtain maximum yields at a cost that make the processes viable for scaling to industrial levels. Finally, these recent discoveries may present a path towards sustainable development in the near future; one that respects and cares for the environment.

\section{Acknowledgements}

We are thankful to Dr. Gregg Orloff (Emory University, Atlanta, USA) for critical revision and comments on this manuscript.

\section{References}

[1] Park, Y.W., Marnet, P.G., Yart, L. and Haenlein, G.F. (2013) Mammary Secretion and Lactation, In: Park, Y.W. and Haenlein, G.F., Eds., Milk and Dairy Products in Human Nutrition: Production, Composition and Health, Wiley, Blackwell, 31-45. http://dx.doi.org/10.1002/9781118534168.ch2

[2] Ramani, W.-B. and Barbara, B. (2013) Milk and Dairy Product Composition. In: Muehlhoff, E., Bennett, A. and McMahon, D., Eds., Milk and Dairy Products in Human Nutrition, Food and Agriculture Organization of the United Nations, Chapter 3, 42-102. http://www.fao.org/docrep/018/i3396e/i3396e.pdf. Accessed 23-07-2014

[3] Schaafsma, G. (2008) Lactose and Lactose Derivates as Bioactive Ingredients in Human Nutrition. International Dairy Journal, 18, 458-465. http://dx.doi.org/10.1016/j.idairyj.2007.11.013

[4] El-Loly, M.M. (2011) Composition, Properties and Nutritional Aspects of Milk Fat Globule Membrane: A Review. Polish Journal of Food and Nutrition Sciences, 61, 7-32. http://dx.doi.org/10.2478/v10222-011-0001-0

[5] Gordon, M.H. (2013) Milk Lipids. In: Park, Y.W. and Haenlein, G.F., Eds., Milk and Dairy Products in Human Nutrition: Production, Composition and Health, Wiley, Blackwell, 65-79.

[6] Cashman, K.D. (2006) Milk Minerals (Including Trace Elements) and Bone Health. International Dairy Journal, 16, 1389-1398. http://dx.doi.org/10.1016/j.idairyj.2006.06.017

[7] Secretaría de economía México (SE) (2012) Dirección general de industrias básicas. Análisis del sector lácteo en México. Análisis del Sector Lácteo en México.

[8] CDICa. The Canadian Dairy Information Centre (2014) Global Consumption of Dairy Products by Country (Annual). http://www.dairyinfo.gc.ca/pdf/consumption_global_milk_e.pdf

[9] Badui Dergal, S. (2006) Química de los alimentos. Pearson Educación, México, 603-617.

[10] Papademas, P. and Bintsis, T. (2010) Food Safety Management Systems (FSMS) in the Dairy Industry: A Review. International Journal of Dairy Technology, 63, 489-503. http://dx.doi.org/10.1111/j.1471-0307.2010.00620.x

[11] CDICb. The Canadian Dairy Information Centre (2014) Global Consumption of Dairy Products by Country (Annual). http://www.dairyinfo.gc.ca/pdf/consumption_global_cheese_e.pdf

[12] CDICc. The Canadian Dairy Information Centre (2014) Global Consumption of Dairy Products by Country (Annual). http://www.dairyinfo.gc.ca/pdf/consumption_global_butter_e.pdf

[13] Ostojić, S., Pavlović, M., Zivić, M., Filipović, Z., Gorjanović, S., Hranisavljević, S. and Dojcinovic, M. (2005) Processing of Whey from Dairy Industry Waste. Environmental Chemistry Letters, 3, 29-32. 
http://dx.doi.org/10.1007/s10311-005-0108-9

[14] Feng, GL., Letey, J., Chang, AC. and Campbell, MM. (2005) Simulatin Dairy Liquid Waste Management Options as a Nitrogen Source for Crops. Agriculture, Ecosystems and Environment, 110, 219-229. http://dx.doi.org/10.1016/j.agee.2005.04.004

[15] Valencia, E. and Ramírez, M.L. (2009) La industria de la leche y la contaminación del agua. Elementos: Ciencia y Cultura, 73, 27-31.

[16] Place, S.E. and Mitloehner, F.M. (2010) Contemporary Environmental Issues: A Review of the Dairy Industry’s Role in Climate Change and Air Quality and the Potential of Mitigation through Improved Production Efficiency. Journal Dairy Science, 93, 3407-3416. http://dx.doi.org/10.3168/jds.2009-2719

[17] Smithers, G.W. (2008) Whey and Whey Proteins_From “Gutter-to-Gold”. International Dairy Journal, 18, 695-704. http://dx.doi.org/10.1016/j.idairyj.2008.03.008

[18] Morales, J., Choi, J.S. and Kim, D.S. (2006) Production Rate of Propionic Acid in Fermentation of Cheese Whey with Enzyme Inhibitors. Environmental Progress, 25, 228-234. http://dx.doi.org/10.1002/ep.10153

[19] Parra Huertas, R.A. (2009) Whey: Importance in the Food Industry. Revista Facultad Nacional de Agronomia Medellin, 62, 4967-4982.

[20] Tovar, J.X., Téllez, J.A., Mercado, F.Y., Abreu, C.A., Muro, U.C., Gómez, A.C.A. and Arana, C.A. (2013) Suero lácteo ¿Solo un residuo o una oportunidad? Ciencia y Desarrollo, 39, 64-69.

[21] Poopathi, S. and Abidha, S. (2012) The Use of Clarified Butter Sediment Waste from Dairy Industries for the Production of Mosquitocidal Bacteria. International Journal of Dairy Technology, 65, 152-157. http://dx.doi.org/10.1111/j.1471-0307.2011.00745.x

[22] Kothari, R., Pathak, V.V., Kumar, V. and Singh, D.P. (2012) Experimental Study for Growth Potential of Unicellular Alga Chlorella pyrenoidosa on Dairy Waste Water: An Integrated Approach for Treatment and Biofuel Production. Bioresource Technology, 116, 466-470. http://dx.doi.org/10.1016/j.biortech.2012.03.121

[23] Neal, C. and Jarvie, H.P. (2005) Agriculture, Community, River Eutrophication and the Water Framework Directive. Hydrological Process, 19, 1895-1901. http://dx.doi.org/10.1002/hyp.5903

[24] Dokulil, M.T. and Teubner, K. (2011) Eutrophication and Climate Change: Present Situation and Future Scenarios. In: Ansari, A.A., Sarvajeet, S.G., Lanza, G.R. and Rast, W., Eds., Eutrophication: Causes, Consequences and Control, Springer, Dordrecht, Heidelberg, London, New York, 1-16.

[25] Tsagaraki, E., Lazarides, H. and Petrotos, K. (2007) Olive Mill Wastewater. In: Oreopoulou, V. and Russ, W., Eds., Utilisation of By-Products and Treatment of Waste in the Food Industry, Springer, New York, 133-157. http://dx.doi.org/10.1007/978-0-387-35766-9_8

[26] Aouidi, F., Khelifi, E. and Asses, N. (2010) Use of Cheese Whey to Enhance Geotrichum candidum Biomass Production in Olive Mill Wastewater. Journal of Industrial Microbiology and Biotechnology, 37, 877-882. http://dx.doi.org/10.1007/s10295-010-0752-3

[27] Páez, G., Jiménez, E., Mármol, Z., Ferrer, J., Sulbarán, B., Ojeda, G., Araujo, K. and Rincón, M. (2008) Perfil de aminoácidos de la proteína unicelular de Kluyveromyces marxianus var marxianus. Interciencia, 33, 297-300.

[28] Pandian, S.R., Deepak, V., Kalishwaralal, K., Rameshkumar, N., Jeyaraj, M. and Gurunathan, S. (2010) Optimization and Fed-Batch Production of PHB Utilizing Dairy Waste and Sea Water as Nutrient Sources by Bacillus megaterium SRKP-3. Bioresource Technology, 101, 705-711. http://dx.doi.org/10.1016/j.biortech.2009.08.040

[29] Pandian, S.R., Deepak, V., Kalishwaralal, K., Jeyaraj, M., Rameshkumar, N. and Gurunathan, S. (2009) Synthesis of PHB Nanoparticles from Optimized Medium Utilizing Dairy Industrial Waste Using Brevibacterium casei SRKP2: A Green Chemistry Approach. Colloids Surf B: Biointerfaces, 74, 266-273. http://dx.doi.org/10.1016/j.colsurfb.2009.07.029

[30] Barnwal, B.K. and Sharma, M.P. (2005) Prospects of Biodiesel Production from Vegetable Oils in India. Renewable and Sustainable Energy Reviews, 9, 363-378. http://dx.doi.org/10.1016/j.rser.2004.05.007

[31] Sivakumar, P., Anbarasu, K. and Renganathan, S. (2011) Bio-Diesel Production by Alkali Catalyzed Transesterification of Dairy Waste Scum. Fuel, 90, 147-151. http://dx.doi.org/10.1016/j.fuel.2010.08.024

[32] Parrondo, J., García, L.A. and Díaz, J.M. (2000) Production of an Alcoholic Beverage by Fermentation of Whey Permeate with Kluyveromyces fragilis I: Primary Metabolism. Journal of the Institute of Brewing, 106, 367-376. http://dx.doi.org/10.1002/j.2050-0416.2000.tb00527.x

[33] Padín González, C. and Díaz Fernández, M. (2006) Efecto de la concentración inicial del lactosuero sobre la fermentación alcohólica con Kluyveromyces fragilis. Revista de la Sociedad Venezolana de Microbiologia, 26, 35-41.

[34] Ozmihci, S. and Kargi, F. (2007) Kinetics of Batch Ethanol Fermentation of Cheese-Whey Powder (CWP) Solution as Function of Substrate and Yeast Concentrations. Bioresource Technology, 98, 2978-2984. 
http://dx.doi.org/10.1016/j.biortech.2006.10.005

[35] Minakshi, D. and Shilpa, V. (2012) Comparative Analysis of Bioethanol Production from Whey by Different Strains of Immobilized Thermotolerant Yeast. International Journal Scientific Research Public, 2, 1-5.

[36] Foda, M.I., Dong, H. and Li, Y. (2010) Study the Suitability of Cheese Whey for Bio-Butanol Production by Clostridia. Journal of American Science, 6, 39-46.

[37] Mathuriya, A.S. and Sharma, V.N. (2009) Bioelectricity Production from Various Wastewaters through Microbial Fuel Cell Technology. Journal Biochemical of Technology, 1, 133-137.

[38] Najafpour, G.D., Rahimnejad, M., Mokhtarian, N., Daud, W.R.W. and Ghoreyshi, A.A. (2010) Bioconversion of Whey to Electrical Energy in a Biofuel Cell Using Saccharomyces cerevisiae. World Applied Sciences Journal, 8, 1-5.

[39] Nasirahmadi, S. and Safekordi, A.A. (2011) Whey as a Substrate for Generation of Bioelectricity in Microbial Fuel Cell Using E. coli. International Journal of Environmental Science and Technology, 8, 823-830. http://dx.doi.org/10.1007/BF03326265

[40] Venkata, M.S., Lalit, B.V. and Sarma, P.N. (2008) Effect of Various Pretreatment Methods on Anaerobic Mixed Microflora to Enhance Biohydrogen Production Utilizing Dairy Wastewater as Substrate. Bioresource Technology, 99, 59-67. http://dx.doi.org/10.1016/j.biortech.2006.12.004

[41] Thangaraj, A. and Kulandaivelu, G. (1994) Biological Hydrogen Photoproduction Using Dairy and Sugarcane Waste Waters. Bioresource Technology, 48, 9-12. http://dx.doi.org/10.1016/0960-8524(94)90127-9

[42] Kothari, R., Pathak, V.V., Kumar, V. and Singh, D.P. (2012) Experimental Study for Growth Potential of Unicellular Alga Chlorella pyrenoidosa on Dairy Waste Water: An Integrated Approach for Treatment and Biofuel Production. Bioresource Technology, 116, 466-470. http://dx.doi.org/10.1016/j.biortech.2012.03.121

[43] Anderson, T.M., Bodie, E.A., Goodman, N. and Schwartz, R.D. (1986) Inhibitory Effect of Autoclaving Whey-Based Medium on Propionic Acid Production by Propionibacterium shermanii. Applied and Environmental Microbiology, 51, 427-428.

[44] Woskow, S.A. and Glatz, B.A. (1991) Propionic Acid Production by a Propionic Acid-Tolerant Strain of Propionibacterium acidipropionici in Batch and Semicontinuous Fermentationt. Applied and Environmental Microbiology, 57, 2821-2828.

[45] Sánchez Toro, Ó.J., Ortiz Buriticá, M.C. and Betancourt Garcés, A.L. (2004) Citric Acid Production from Whey by Fermentation Using Aspergillus spp. Revista Colombiana de Biotecnologia, 6, 43-54.

[46] Wan, C., Li, Y., Shahbazi, A. and Xiu, S. (2008) Succinic Acid Production from Cheese Whey Using Actinobacillus succinogenes 130Z. Applied Biochemistry and Biotechnology, 145, 111-119. http://dx.doi.org/10.1007/s12010-007-8031-0

[47] Alonso, S., Herrero, M., Rendueles, M. and Díaz, M. (2010) Residual Yoghurt Whey for Lactic Acid Production. Biomass and Bioenergy, 34, 931-938. http://dx.doi.org/10.1016/j.biombioe.2010.01.041

[48] El-Holi, M.A. and Al-Delaimy, K.S. (2003) Citric Acid Production from Whey with Sugars and Additives by Aspergillus niger. African Journal of Biotechnology, 2, 356-359. http://dx.doi.org/10.5897/AJB2003.000-1073

[49] Plessas, S., Bosnea, L., Psarianos, C., Koutinas, A., Marchant, R. and Banat, I.M. (2008) Lactic Acid Production by Mixed Cultures of Kluyveromyces marxianus, Lactobacillus delbrueckii ssp. bulgaricus and Lactobacillus helveticus. Bioresource Technology, 99, 5951-5955. http://dx.doi.org/10.1016/j.biortech.2007.10.039

[50] Gutiérrez, L.-F., Hamoudi, S. and Belkacemi, K. (2012) Lactobionic Acid: A High Value-Added Lactose Derivative for Food and Pharmaceutical Applications. International Dairy Journal, 26, 103-111. http://dx.doi.org/10.1016/j.idairyj.2012.05.003

[51] Vlad-Cristea, M.S. (2007) Production of Bioactive Lactobionic Acid Using a Novel Catalytic Method. M.Sc. Dissertation, Université Laval Québec, Québec, 1-102. http://www.theses.ulaval.ca/2007/24772/24772.pdf

[52] Miyamoto, Y., Ool, T. and Kinoshita, S. (2000) Production of Lactobionic Acid from Whey by Pseudomonas sp. LS13-1. Biotechnology Letters, 22, 427-430. http://dx.doi.org/10.1023/A:1005617903152

[53] Alonso, S., Rendueles, M. and Díaz, M. (2011) Efficient Lactobionic Acid Production from Whey by Pseudomonas taetrolens under $\mathrm{pH}$-Shift Conditions. Bioresource Technology, 102, 9730-9736. http://dx.doi.org/10.1016/j.biortech.2011.07.089

[54] Maddox, I.S. and Richert, S.H. (1977) Production of Gibberellic Acid Using a Dairy Waste as the Basal Medium. Applied and Environment Microbiology, 33, 201-202.

[55] Mukherjee, S., Das, P. and Sen, R. (2006) Towards Commercial Production of Microbial Surfactants. Trends Biotechnology, 24, 509-515. http://dx.doi.org/10.1016/j.tibtech.2006.09.005

[56] Rodrigues, L., Banat, I.M., Teixeira, J. and Oliveira, R. (2006) Biosurfactants: Potential Applications in Medicine. 
Journal of Antimicrobial Chemotherapy, 57, 609-618. http://dx.doi.org/10.1093/jac/dkl024

[57] Saharan, B.S., Sahu, R.K. and Sharma, D. (2011) A Review on Biosurfactants: Fermentation, Current Developments and Perspectives. Genetic Engineering \& Biotechnology Journal, 2011, 1-14.

[58] Daverey, A., Pakshirajan, K. and Sangeetha. P. (2009) Sophorolipids Production by Candida bombicola Using Synthetic Dairy Wastewater. International Scholarly and Scientific Research and Innovation, 3, 466-468.

[59] Gomaa, E.Z. (2013) Antimicrobial Activity of a Biosurfactant Produced by Bacillus licheniformis Strain M104 Grown on Whey. Brazilian Archives of Biology and Technology, 56, 259-268. http://dx.doi.org/10.1590/S1516-89132013000200011

[60] Colak, A.K. and Kahraman, H. (2013) The Use of Raw Cheese Whey and Olive Oil Mill Wastewater for Rhamnolipid Production by Recombinant Pseudomonas aeruginosa. Environmental and Experimental Biology, 11, 125-130.

[61] Fuentes, Á., Carreño, C. and Llanos, C. (2013) Yield Emulsifiers Exopolysaccharides Produced by Native Halophilic Bacteria Concentrations Molasses Three Saccharum officinarum L. “Sugarcane”. Scientia Agropecuaria, 4, 111-120.

[62] Wilches Flórez, A.M. (2005) Estudio genético preliminar de bacterias ácido lácticas productoras de exopolisacáridos (EPS). Bistua: Revista de la Facultad de Ciencias Básicas, 3, 12-18.

[63] Tiehua, Z., Chunhong, Z., Shengyu, L., Yanchun, Z. and Zhennai, Y. (2011) Growth and Exopolysaccharide Production by Streptococcus thermophilus ST1 in Skim Milk. Brazilian Journal of Microbiology, 42, 1470-1478. http://dx.doi.org/10.1590/S1517-83822011000400033

[64] Amjres, H., Béjar, V., Quesada, E., Abrini, J. and Llamas, I. (2010) Pharmaceutical Applications of the Exopolysaccharides Produced by Halomonas nitroreducens Strain HK30. ARS Pharmaceutica, 51, 255-266.

[65] Briczinski, E.P. and Roberts, R.F. (2002) Production of an Exopolysaccharide-Containing Whey Protein Concentrate by Fermentation of Whey. Journal of Dairy Science, 85, 3189-3197. http://dx.doi.org/10.3168/jds.S0022-0302(02)74407-X

[66] Ricciardi, A., Parente, E., Crudele, M.A., Zanetti, F., Scolari, G. and Mannazzu. I. (2002) Exopolysaccharide Production by Streptococcus thermophilus SY: Production and Preliminary Characterization of the Polymer. Journal of Applied of Microbiology, 92, 297-306. http://dx.doi.org/10.1046/j.1365-2672.2002.01487.x

[67] Baró, L., Jiménez, J., Martínez-Férez, A. and Bouza, J.J. (2001) Bioactive Milk Peptides and Proteins. ARS Pharmaceutica, 42, 135-145.

[68] Krissansen, G.W. (2007) Emerging Health Properties of Whey Proteins and Their Clinical Implications. Journal of American College of Nutrition, 26, 713S-723S. http://dx.doi.org/10.1080/07315724.2007.10719652

[69] Madureira, A., Pereira, C., Gomes, A., Pintado, M. and Malcata, F. (2007) Bovine Whey Proteins—Overview on Their Main Biological Properties. Food Research International, 40, 1197-1211. http://dx.doi.org/10.1016/j.foodres.2007.07.005

[70] Haque, E. and Chand, R. (2008) Antihypertensive and Antimicrobial Bioactive Peptides from Milk Proteins. European Food Research Technology, 227, 7-15. http://dx.doi.org/10.1007/s00217-007-0689-6

[71] Alvarado-Carrasco, C. and Guerra, M. (2010) Lactosuero como fuente de péptidos bioactivos. Anales Venezolanos de Nutrición, 23, 42-49.

[72] Mulero, C.J., Zafrilla, R.P., Martínez-Cachá Martínez, A., Leal, H.M. and Abellán, A.J. (2011) Péptidos Bioactivos. Clínica e Investigacion en Arteriosclerosis, 23, 219-227. http://dx.doi.org/10.1016/j.arteri.2011.04.004

[73] Korhonen, H. and Pihlanto, A. (2006) Bioactive Peptides: Production and Functionality. International Dairy Journal, 16, 945-960. http://dx.doi.org/10.1016/j.idairyj.2005.10.012

[74] Korhonen, H. (2009) Milk-Derived Bioactive Peptides: From Science to Applications. Journal of Functional Foods, 1, 177-187. http://dx.doi.org/10.1016/j.jff.2009.01.007

[75] Corrons, M.A., Bertucci, J.I., Liggieri, C.S., López, L.M.I. and Bruno, M.A. (2012) Milk Clotting Activity and Production of Bioactive Peptides from Whey Using Maclura pomifera Proteases. Food Science and Technology, 47, 103109. http://dx.doi.org/10.1016/j.lwt.2011.12.028

[76] Narva, M. (2004) Effects of Lactobacillus helveticus Fermented Milk and Milk-Derived Bioactive Peptides (CPP, IPP and VPP) on Calcium and Bone Metabolism. Helsinki, Finland. Doctoral Dissertation, Institute of Biomedicine, Pharmacology University of Helsinki, 83. http://ethesis.helsinki.fi/julkaisut/laa/biola/vk/narva/effectso.pdf

[77] Reyes-Nava, L.A., Briones-Martínez, R. and Cortés-Vázquez, M.I. (2006) Funcionalidad de péptidos catiónicos y aniónicos producidos por hidrólisis enzimática de proteínas de suero lácteo. V Memories international congress of biochemical engineering, XVI National congress of biochemical engineering, VI Scientific Conference of Molecular Biomedicine and Biotechnology. VI JC de Biomedicina, B Molecular. Tuxtla Gutiérrez Chiapas, México. http://www.informatica.sip.ipn.mx/colmex/congresos/chiapas/cd/Alimentos\%5CResumen\%5C497800.pdf 
[78] Alvarado-Carrasco, C., Gómez-Ruiz, J. and Guerra M. (2012) Actividad inhibidora de la enzima convertidora de la angiotensina de un hidrolizado de lactosuero de cabra con proteasa de Aspergillus oryzae. http://saber.ucv.ve/jspui/bitstream/123456789/1461/1/art\%C3\%ADculo\%20PL-05\%202011.pdf

[79] Santana de Souza, M.W., Rolim Biasutti, E.A., Linhares Carreira, R. and Oliveira Afons, W. (2008) Obtaining Oligopeptides from Whey: Use of Subtilisin and Pancreatin. American Journal of Food Technology, 3, 315-324. http://dx.doi.org/10.3923/ajft.2008.315.324

[80] Antonio, G., Fernando, C. and Emilia, M.G. (2006) Production of Whey Protein Hydrolysates with Reduced Allergenicity in a Stable Membrane Reactor. Journal of Food Engineering, 72, 398-405.

http://dx.doi.org/10.1016/j.jfoodeng.2004.12.022 